\title{
Efficient conversion of conjugated linoleic acid c9,t11 by Lactobacillus fermentation from vegetable oil to generate fermented milk with high CLA content
}

\author{
Hee-Sun Yang ${ }^{1}$, Sang-Cheon Lee ${ }^{2}$, Chang-Ki Huh ${ }^{3 *}$ \\ ${ }^{1}$ Department of Food and Nutrition, Sunchon National University, Suncheon 57922, Korea \\ ${ }^{2}$ Imsil Cheese and Food Research Institute, Imsil 55918, Korea \\ ${ }^{3}$ Department of Food Science and Technology, Sunchon National University, Suncheon 57922, Korea
}

\begin{abstract}
The purpose of this study was to develop a functional and valuable dairy product with high conjugated linoleic acid (CLA) content through a fermentation method utilizing vegetable oil and probiotic lactic acid bacteria. Bifidobacterium breve KCTC 3419 was selected as a standard strain for high efficiency conversion of the CLA c9,t11. This standard strain was mixed in a definite ratio of 4:3:3 with Lactobacillus sakei LJ011 isolated from kimchi and the commercially available YF-L812 culture to generate a high-efficiency CLA conversion starter stock for use in fermented milk production. CLA conversion by safflower seed oil fermentation by the starter stock yielded the highest CLA containing fermented milk. The pH level, titratable acidity, and number of lactic acid bacteria in the fermented milk were altered to suitable levels during the fermented milk production process. The CLA content of CLA-fermented milk was maintained at $0.1 \%$ of the total CLA content during the storage period of 2 weeks.
\end{abstract}

Key words : conjugated linoleic acid, Lactobacillus fermentation, conjugated linoleic acid conversion starter stock, safflower seed oil, fermented milk

\section{Introduction}

Conjugated linoleic acid (CLA) is a mixture of cis and trans geometrical isomers of linoleic acid (LA) that have conjugated double bonds. The abundantly found isomers of CLA have double bonds at positions 8,$10 ; 9,11 ; 10,12$; and $11,13(1,2)$. In the past, before CLA was first identified, it was consumed naturally and adequately as part of the general diet. However, since the 1970s, changes in dietary habits and livestock breeding have led to a decrease in the natural intake of CLA (3). Michael Pariza and his research team from the University of Wisconsin first described CLA in 1985. CLA as an anti-mutagenic agent was isolated from fried ground beef during research on anti-cancer activity $(4,5)$. It

*Corresponding author. E-mail : hck1008@sunchon.ac.kr Phone : 82-61-750-3251, Fax : 82-61-750-3208

Received 23 March 2018; Revised 27 June 2018; Accepted 2 July 2018.

Copyright (c) The Korean Society of Food Preservation. All rights reserved. has since been detected in many dairy foods and the flesh of ruminants.

CLA has been actively researched (6-8) since the late 1990s. During that period, human clinical trials were conducted addressing the effects of CLA on body fat reduction, leading to an explosive growth of CLA as the first diet food product in the USA (9). CLA has been associated with a multitude of effects including anti-cancer (10), anti-diabetic (11), cholesterol-lowering (12), immune enhancement (13), and antioxidant (14) effects, and effects on women's health (15). CLA-containing foods include milk products such as milk and cheese, which are synthesized from linoleic acid by microorganisms living in the rumen of mammals $(5,16,17)$. In addition, CLA is present in beef, chicken, eggs, and safflower seed oil (18-20).

CLA is necessary to develop high value-added and high function dairy products that meet modern dairy industry standards and to develop valuable dairy products that can be imported and exported. CLA production methods involve either microbial fermentation or chemical synthesis. Linoleic 
acid, present in safflower seed oil and sunflower oil, is used for CLA production by chemical methods (21). The chemical synthesis method is only used due to the residual substances derived from the chemical used in synthesis $(21,22)$. It is, however, desirable to synthesize CLA by more natural means, via microbial synthesis especially from probiotic bacteria that can be grafted with dairy products $(23,24)$. Naturally occurring CLA produced by microbial fermentation has been attributed with beneficial effects on human health. Lactobacillus, Bifidobacteria, and Propionibacteria have the ability to convert linoleic acid to CLA (25). The main disadvantage, however, has been the low yield obtained from microbial methods when compared to high-yielding chemical methods. Therefore, it is essential to develop new and efficient techniques for the increase of the fermentation products. The purpose of this study was to develop a high quality functional dairy product with increased CLA content through an eco-friendly fermentation method, utilizing probiotic lactic acid bacteria and vegetable oil materials.

\section{Materials and methods}

\section{Materials}

Raw milk for production of fermented milk was obtained an acidity of $0.15 \%$ and a $\mathrm{pH}$ of 6.8 from the Holstein-Friesian breed of dairy cattle of the Imsil area (Korea). Soybean oil, corn oil, sunflower oil, grape seed oil, canola oil, olive oil, rice oil, sesame oil, and perilla oil were purchased from Sajo Company (Seoul, Korea). Pumpkin seed oil, walnut oil, safflower seed oil, and flaxseed oil were purchased from Jeongwoodang Company (Seoul, Korea). Lactic acid bacteria for the production of fermented milk included commercial strain YF-L812 (Streptococcus thermophilus, Lactobacillus delbrueckii subsp. bulgaricus), standard strain Bifidobacterium breve KCTC 3419, and Lactobacillus sakei subsp. LJ011 (isolated from kimchi). These strains were cultured twice in sterilized $10 \%$ skim milk, and starter stocks were prepared by mixing the three bacterial strains in a ratio of $4: 3: 3$. The reagents used for extraction and instrumental analysis were above reference grade and purchased from Sigma chemical Co. (St. Louis, Mo, USA).

\section{CLA production analysis}

In this study, we followed the analytical methods described by Ledoux et al. (26), Werner et al. (27), and Kim and Liu (28) to establish optimal analysis conditions of CLA fatty acids. Gas chromatography (GC, Agilent, USA) for fatty acid analysis was performed using a Supelcoax-10 fused capillary GC column (Supelco, $60 \mathrm{~m} \times 0.32 \mathrm{~mm}, 0.25 \mu \mathrm{m}$ ). Analysis conditions were as follows: helium gas $1 \mathrm{~mL} / \mathrm{min}$, split ratio $50: 1$, injector temperature $250^{\circ} \mathrm{C}$, detector temperature $260^{\circ} \mathrm{C}$, and column oven temperature $190^{\circ} \mathrm{C}$ at $4.5^{\circ} \mathrm{C} / \mathrm{min}$ maintained for $15 \mathrm{~min}$. Analysis of each fatty acid was compared with the retention time of each standard fatty acid.

Thirty different strains of CLA-producing standard lactic acid bacteria and six strains of Lactobacillus species, isolated from fermented kimchi, were cultured in MRS medium supplemented with linoleic acid $(2 \mathrm{mM})$ and tested for production patterns of CLA isomers by fermentation. Kimchi for isolation of lactic acid bacteria was obtained from different manufacturing sources at Jeonju City, Imsil County of Jeollabukdo, Gwangyang City of Jeollanamdo, and Kyonggido. We estimated the total amount of CLA produced, as well as the amount and ratios of CLA isomers, including cis9; trans11 CLA, to test for efficient CLA production by using methods mentioned above.

\section{Manufacture of starter stock for high efficiency CLA conversion}

The ratio of commercial strains to standard lactic acid bacteria and lactic acid bacteria isolated from kimchi were varied and tested for stock production of a high efficiency CLA conversion starter. The amount of CLA (c9,t11) produced was specifically estimated and compared. To check efficiency of CLA conversion starter stock on milk, $0.05 \%$ linoleic acid was added to either $10 \%$ skim milk powder, low-fat milk (fat content $2 \%$ ), or raw milk. This was inoculated with a $3 \%$ starter stock (that had been cultured in MRS for $24 \mathrm{~h}$ ) and further incubated at $37^{\circ} \mathrm{C}$ for $48 \mathrm{~h}$. The CLA production was then estimated to check efficiency.

The novel efficient CLA conversion starter stock described in this study was prepared by mixing the commercial strains YF-L812 (Streptococcus thermophilus, Lactobacillus delbrueckii subsp. Bulgaricus), Bifidobacterium breve KCTC3419, and Lactobacillus sakei subsp LJ011 strain in a ratio of 4:3:3 and incubating it in MRS medium for $24 \mathrm{~h}$. The cultured starter stock (3\%) was then taken and added to raw milk and further incubated at $37^{\circ} \mathrm{C}$ for $48 \mathrm{~h}$

Determination of type and amount of vegetable oil required for obtaining high CLA content

The above mentioned 14 types of vegetable oil were individually added to $0.05 \%$ raw milk and then incubated 
with $3 \%$ cultured lactic acid bacteria (previously cultured in MRS medium for $24 \mathrm{~h}$ ) at $37^{\circ} \mathrm{C}$ for $9 \mathrm{~h}$, after which CLA content was measured. A similar procedure was followed to check efficiency of CLA production under varying amounts of safflower seed oil, which varied from 0.01-0.5\%.

\section{Manufacture of fermented milk}

Fermented milk was prepared by adding $5 \%$ fructooligosaccharide to raw milk, followed by sterilization at $90^{\circ} \mathrm{C}$ for $10 \mathrm{~min}$ and cooling to $45^{\circ} \mathrm{C}$. Then, $0.1 \%$ safflower seed oil and starter stock were inoculated at $3 \%$ and cultured at $42^{\circ} \mathrm{C}$ for $9 \mathrm{~h}$ until a $\mathrm{pH}$ of 4.6 was achieved, which indicates fermented milk containing a high CLA concentration. The fermented milk was then supplemented with CLA (mg/g), homogenized, and cooled to $15^{\circ} \mathrm{C}$. Fermented milk was stored in a closed container at $4^{\circ} \mathrm{C}$ (Fig. 1.). agar medium. The number of yellow colonies was measured and expressed as CFU (colony forming unit)/mL. Changes in $\mathrm{pH}$, titratable acidity, and number of lactic acid bacteria were measured during storage for 28 days at weekly intervals while refrigerated at $4^{\circ} \mathrm{C}$. For fermented milk containing CLA, the degree of change in CLA content during storage was checked by GC analysis for 28 days from 7 days after the manufacture of the product.

\section{Statistical methods}

Data has been expressed as mean \pm SD. Statistical analysis for single comparisons was performed using Duncan's multiple range test. Each experiment was repeated at least three times to yield comparable results. Null hypotheses of no difference were rejected if p-values were less than 0.05 .

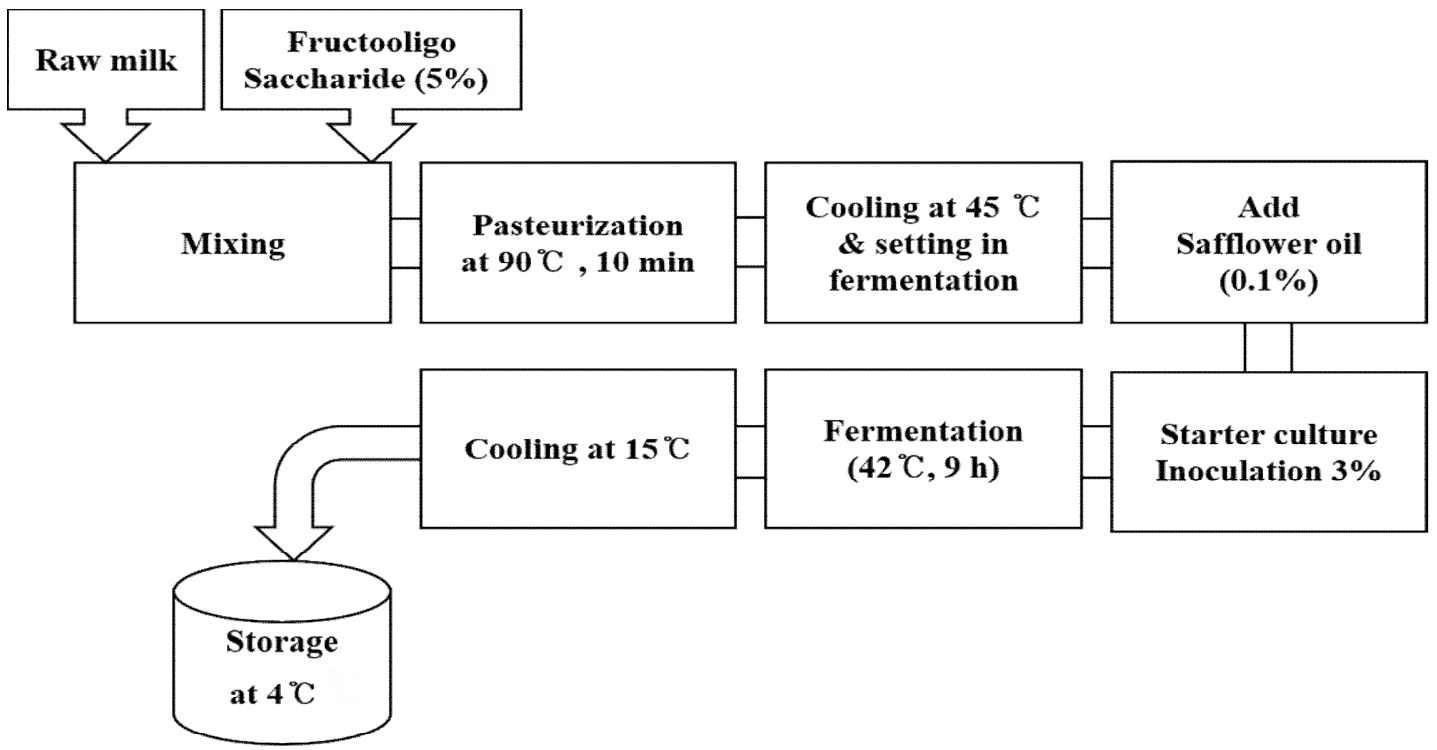

Fig. 1. Manufacturing process of CLA fermented milk.

\section{Evaluation of quality characteristics of fermented milk}

Changes in $\mathrm{pH}$, titratable acidity, and number of lactic acid bacteria were measured during the fermentation process at $3 \mathrm{~h}$ intervals for $24 \mathrm{~h}$. The $\mathrm{pH}$ level was measured using a $\mathrm{pH}$ meter (UB-10, Denver, USA). The titration was carried out by adding $10 \mathrm{~mL}$ of distilled water to $10 \mathrm{~mL}$ of sample to obtain a suspension. The suspension was titrated to $\mathrm{pH}$ 8.3 by adding $\mathrm{NaOH}$, and the weight $(\mathrm{g})$ of the specimen was divided to obtain the titratable acidity (\%). The change in lactic acid bacteria count was obtained by taking $1 \mathrm{~mL}$ of the sample, diluting it in sterilized saline by the decimal dilution method, and culturing it at $37^{\circ} \mathrm{C}$ for $48 \mathrm{~h}$ in BCP

\section{Results and discussion}

Selection of lactic acid bacteria for high efficiency CLA conversion

Among the standard lactic acid bacteria tested, three strains of Lactobacillus acidophilus, one strain of Lactobacillus casei, two strains of Lactobacillus rhamnosus, two strains of Streptococcus thermophilus, two strains of Bifidobacterium bifidum, two strains of Bifidobacterium breve, and two strains of Bifidobacterium longum were found to produce CLA (Table 1). Among these Bifidobacterium breve, KCTC3419 yielded highest CLA conversion. However, fermentation using the different strains reduced upon addition of substrate 
(10-20 $\mathrm{\mu g} / \mathrm{mL}$ of CLA conversion). CLA consists of several possible isomers $\mathrm{c} 9, \mathrm{t} 11 ; \mathrm{t} 10, \mathrm{c} 12 ; \mathrm{t} 9, \mathrm{t} 11 ; \mathrm{t} 10, \mathrm{t} 12 ; \mathrm{c} 9, \mathrm{c} 11$; t9,c11; c10,c12; and c10,t12. The isomer associated with important physiological activity in the human body is the cis9,trans11 CLA (29). Gorissen et al. (30) reported that Bifidobacteria produced high amounts of CLA and CLA isomers, and Bifidobacterium breve LMG 13194 strain produced large amounts of c9,t11-CLA. Similar results were obtained in this study. We, therefore, selected the strain Bifidobacterium breve KCTC3419 to use in the preparation

Table 1. Production of CLA by different strains of lactic acid bacteria

\begin{tabular}{|c|c|c|}
\hline \multicolumn{2}{|c|}{ Standard lactic acid bacteria } & CLA contents \\
\hline \multirow{6}{*}{ Lactobacillus acidophillus } & KCTC3140 & $++^{1)}$ \\
\hline & КСТС3171 & - \\
\hline & КСТС 3151 & + \\
\hline & KCCM 32820 & - \\
\hline & KCCM41270 & - \\
\hline & KCCM41619 & + \\
\hline \multirow{2}{*}{ Lactobacillus casei } & КСТС3260 & + \\
\hline & КСТC3189 & - \\
\hline \multirow{2}{*}{ Lactobacillus gasseri } & КСТC3163 & - \\
\hline & КСТC3173 & - \\
\hline Lactobacillus paracasei & КСТC13169 & - \\
\hline \multirow{2}{*}{ Lactobacillus rhamnosus } & КСТC5033 & + \\
\hline & KCCM32411 & + \\
\hline \multirow{5}{*}{ Streptococcus thermophilus } & KCTC3782 & + \\
\hline & КСТС3779 & - \\
\hline & КCTC3780 & + \\
\hline & КСТС5098 & - \\
\hline & КСТC5092 & - \\
\hline \multirow{2}{*}{ Bifidobacterium bifidum } & КCTC3418 & + \\
\hline & КСТС3440 & + \\
\hline \multirow{2}{*}{ Bifidobacterium breve } & КСТC3220 & + \\
\hline & КСТС3419 & ++ \\
\hline \multirow{3}{*}{ Bifidobacterium longum subsp. infantis } & КСТС 3249 & - \\
\hline & КСТС 3460 & - \\
\hline & КСТС 3127 & - \\
\hline \multirow{2}{*}{ Bifidobacterium longum } & КСТC3421 & + \\
\hline & КСТС 3420 & + \\
\hline \multirow{2}{*}{ Lactobacillus helveticus } & KCCM40989 & - \\
\hline & KCCM41823 & - \\
\hline \multicolumn{3}{|l|}{ Lactic acid bacteria isolated from kimch } \\
\hline \multirow{3}{*}{ Lactobacillus sakei subsp. } & LJ011 & +++ \\
\hline & LI033 & ++ \\
\hline & LGy039 & ++ \\
\hline \multirow{3}{*}{ Pediococcus pentosaceus } & LJ015 & - \\
\hline & LJ024 & - \\
\hline & LJ026 & - \\
\hline
\end{tabular}

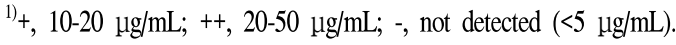

of starter stock culture for efficient CLA conversion.

Among the lactobacilli isolated from kimchi, Lactobacillus sakei subsp. LJ011, Lactobacillus sakei subsp. LI033, and Lactobacillus sakei subsp. LGy039 converted the substrateinto CLA (Table 1). The CLA conversion rate of Lactobacillus sakei subsp. LJ011 was found to be the highest at $67 \mathrm{\mu g} / \mathrm{mL}$. Therefore, this strain was selected and used in the preparation of starter stock culture for the high efficiency CLA conversion. Renes et al. (31) reported that co-cultures of Lactobacillus strains are effective for increasing CLA conversion. In this study, we tried to further increase the CLA conversion rate by mixing the standard Bifidobacterium breve KCTC3419 strain and Lactobacillus sakei subsp. LJ011 strain isolated from kimchi.

\section{Manufacture of CLA conversion starter stock}

Fermentation speed, quality, and sensory characteristics are important considerations for the starter stocks used in fermented milk (32). Lee et al. (33) reported that when fermented milk is prepared by mixing commercial starter with functional lactic acid bacterium, quality could be improved with the desired functionality. We, therefore, mixed the commercial strains YF-L812 (Streptococcus thermophilus, Lactobacillus delbrueckii subsp. Bulgaricus), Bifidobacterium breve KCTC3419, and Lactobacillus sakei subsp LJ011 strain in varying proportions and cultured it in MRS medium. This mixture was then added to substrate containing linoleic acid and tested for efficient CLA conversion. In our study, a ratio of 4:3:3 of YF-L812, Bifidobacterium breve KCTC3419 and Lactobacillus sakei subsp LJ011 strain yielded the highest CLA conversion rate (Table 2).

\section{Characteristics of CLA production using efficient CLA conversion starter stock}

To characterize the CLA conversion rates of the starter stock, depending on the media used, we added linoleic acid to $10 \%$ skim milk, low-fat milk ( $2 \%$ fat content), or raw milk and then incubated it with the CLA conversion starter stock. We compared the production of CLA $(\mathrm{c} 9, \mathrm{t} 11)$ among the three media used. The amount of CLA production in each medium tended to increase until $24 \mathrm{~h}$ after fermentation, after which no significant increase was observed till $48 \mathrm{~h}$ (Fig. 2). CLA production was found to be highest in raw milk medium, with $167 \mathrm{\mu g} / \mathrm{mL}$ being produced after $9 \mathrm{~h}$ of fermentation, and $207 \mu \mathrm{g} / \mathrm{mL}$ after $24 \mathrm{~h}$ of fermentation (Fig. 2), suggesting that higher fat content was associated with higher CLA production. Trigueros and Sendra (34) performed 
fermentation of high-fat, full-fat, and low-fat milk types to compare CLA content and reported a production of 93.33 $\mu \mathrm{g} / \mathrm{mL}$ from high fat milk, which is only half the amount that we could produce with our starter stock. Thus, the starter stock generated in our study is capable of efficiently increasing CLA production.

To further establish the characteristics of the use of CLA conversion starter stock, we inoculated raw milk with $3 \%$ starter stock and cultured it at $37^{\circ} \mathrm{C}$ for $48 \mathrm{~h}$. We then measured the $\mathrm{pH}$ of the fermented milk and viable cell counts. The $\mathrm{pH}$ level of the fermented milk cultured in starter stock for

Table 2. Production of CLA under varying ratios of the cultures used in the preparation of the starter stock

\begin{tabular}{|c|c|}
\hline Starter stock mixing ratio & CLA contents \\
\hline YF-L812(8) : B. breve KCTC 3419(1) : L. sakei subsp. LJ011(1) & $++^{1)}$ \\
\hline YF-L812(7) : B. breve KCTC 3419(1) : L. sakei subsp. LJ011(2) & + \\
\hline YF-L812(7) : B. breve KCTC 3419(2) : L sakei subsp. LJ011(1) & + \\
\hline YF-L812(6) : B. breve KCTC 3419(2) : L. sakei subsp. LJ011(2) & + \\
\hline YF-L812(6) : B. breve KCTC 3419(1) : L. sakei subsp. LJ011(3) & ++ \\
\hline YF-L812(6) : B. breve KCTC 3419(3) : L. sakei subsp. LJ011(1) & + \\
\hline YF-L812(5) : B. breve KCTC 3419(2.5) : L. sakei subsp. LJ011(2.5) & + \\
\hline YF-L812(5) : B. breve KCTC 3419(3) : L. sakei subsp. LJ011(2) & + \\
\hline YF-L812(5) : B. breve KCTC 3419(2) : L. sakei subsp. LJ011(3) & ++ \\
\hline YF-L812(5) : B. breve KCTC 3419(4) : L. sakei subsp. LJ011(1) & + \\
\hline YF-L812(5) : B. breve KCTC 3419(1) : L. sakei subsp. LJ011(4) & ++ \\
\hline YF-L812(4) : B. breve KCTC 3419(3) : L. sakei subsp. LJ011(3) & ++++ \\
\hline YF-L812(4) : B. breve KCTC 3419(2) : L. sakei subsp. LJ011(4) & +++ \\
\hline YF-L812(4) : B. breve KCTC 3419(4) : L. sakei subsp. LJ011(2) & ++ \\
\hline YF-L812(4) : B. breve KCTC 3419(1) : L. sakei subsp. LJ011(5) & +++ \\
\hline
\end{tabular}

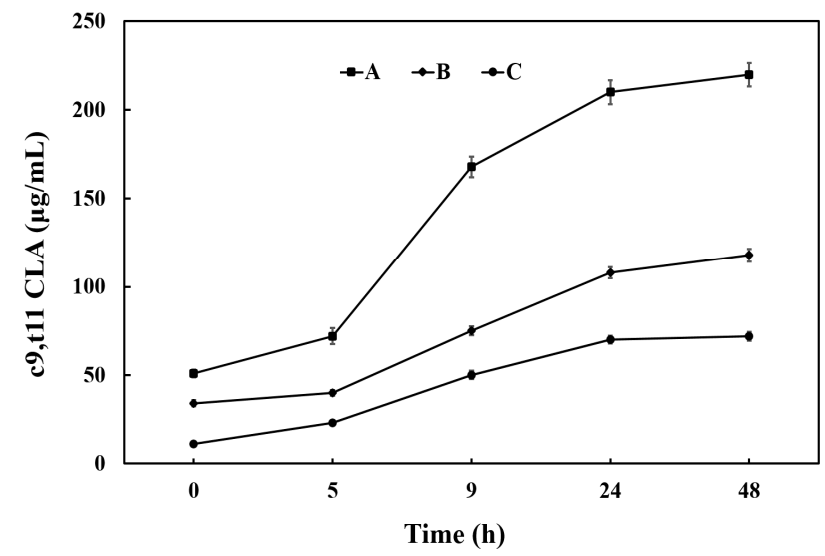

Fig. 2. Comparison of the CLA production efficiency of the starter stock in different media conditions.

A, raw milk; B, low fat milk; $\mathrm{C}$, skim milk.
CLA conversion was found to decrease in proportion to incubation time with the $\mathrm{pH}$ measuring 4.72 after $9 \mathrm{~h}$ of fermentation. Additionally, the number of lactic acid bacteria was found to be about $10^{9} \mathrm{CFU} / \mathrm{mL}$ after $9 \mathrm{~h}$ of fermentation (data not shown). This result indicates that the starter stock may indeed have excellent applicability to produce functional fermented milk with highly efficient CLA conversion.

\section{Selection of vegetable oil for CLA production}

To confirm the CLA conversion rate of vegetable oil during fermentation by CLA conversion starter stock, 14 species of vegetable oil were individually added to raw milk and inoculated with the starter stock. The results are shown in Fig. 3. The CLA production from pure linoleic acid was 38.07 $\mathrm{mg} / 100 \mathrm{~mL}$. The conversion rate, as estimated from the CLA content, was found to be high in safflower seed oil (48.24 $\mathrm{mg} / 100 \mathrm{~mL})$, walnut oil (38.18 mg/100 mL), and sunflower oil $(34.21 \mathrm{mg} / 100 \mathrm{~mL})$. In fact, safflower seed oil showed higher production than linoleic acid. Thus, safflower seed oil, which is cheaper than linoleic acid, can be used as a substrate in the production of CLA fermented milk. Safflower seed oil has a high content of linoleic acid $(35,36)$ and Ivan et al. (37) reported that the CLA production capacity of safflower seed oil is high. Therefore, in this study, we decided to use safflower seed oil as a substrate for the production of CLA during milk fermentation.

We next estimated the amount of safflower seed oil that can be used efficiently during fermentation by CLA conversion starter stock. The CLA content was measured after

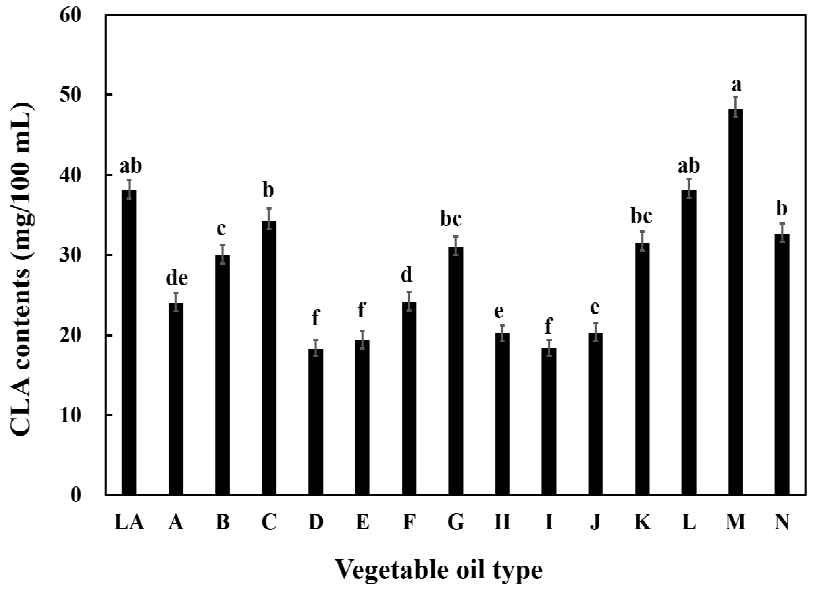

Fig. 3. Comparison of CLA conversion rates using different vegetable oils as substrates.

LA, linoleic acid; A, soybean oil; B, corn oil; C, sunflowers oil; D, grape seed oil; E, canola oil; F, olive oil; G, brown rice oil; $\mathrm{H}$, rice germ oil; I, sesame oil; J, perilla oil; K, pumpkin seed oil; L, walnut oil; M, safflower seed oil; N, flaxseed oil. Means in the same bar followed by different uppercase letters are significantly different $(\mathrm{p}<0.05, \mathrm{a}>\mathrm{b}>\mathrm{c}>\mathrm{d}>\mathrm{e}>\mathrm{f})$. 
fermentation of raw milk using 3\% starter stock, and supplementation with 0.01 to $0.5 \%$ safflower seed oil. Weobserved that CLA production increased with increasing concentrations of safflower seed oil in the fermented milk (Fig. 4). Conversion of CLA by $0.1 \%$ safflower seed oil added to the sample was found to be the most efficient. Therefore,

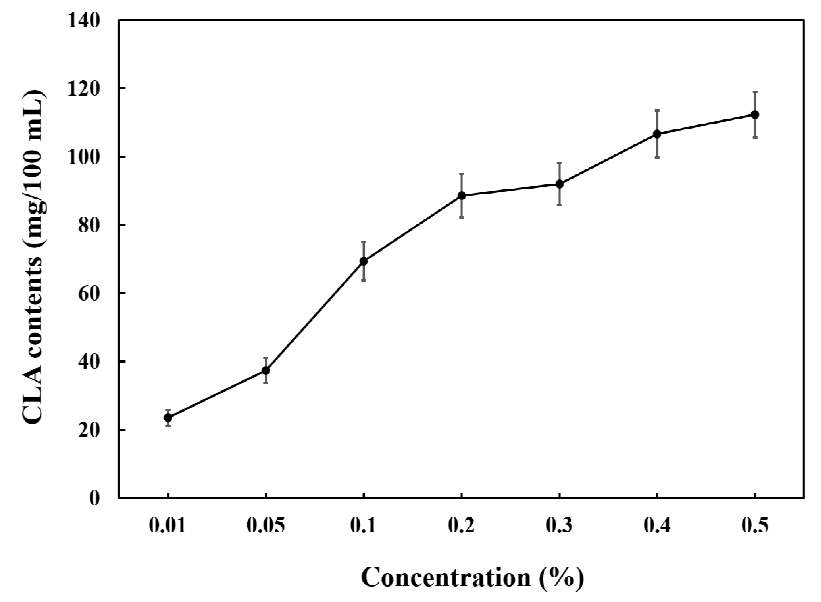

Fig. 4. CLA conversion rate across different concentrations of safflower seed oil (substrate). in the production of fermented milk, we used a $0.1 \%$ concentration of safflower seed oil.

\section{Quality characteristics of fermented milk}

Fermented milk was prepared (as described in the methods) to investigate the possibility of producing fermented milk using starter stock for CLA conversion. We analyzed the quality of the fermentation process by estimating $\mathrm{pH}$, titratable acidity, and number of lactic acid bacteria in fermented milk, during fermentation (Table 3). Fermented milk reached a fermentation end point at $\mathrm{pH} 4.6$ within $9 \mathrm{~h}$ of fermentation, with a titratable acidity value of $0.85 \%$, and lactic acid bacteria count of $1.2 \times 10^{9} \mathrm{CFU} / \mathrm{mL}$. There was no significant difference observed in the quality characteristics of fermented milk in presence or absence of safflower seed oil. This is consistent with previous report in which addition of flower oil did not affect characteristics of fermented milk (38). Therefore, it is possible to manufacture fermented milk using starter stock for CLA conversion after addition of safflower seed oil as a substrate for CLA conversion.

Changes in $\mathrm{pH}$, titratable acidity, number of lactic acid

Table 3. Characteristics of fermented milk during fermentation

\begin{tabular}{cccccccccc}
\hline & & \multicolumn{7}{c}{ Fermentation time (h) } \\
\cline { 3 - 9 } & & & 0 & 3 & 6 & 9 & 12 & 15 & 24 \\
\hline \multirow{2}{*}{$\mathrm{pH}$} & Safflower seed oil & $0 \%$ & $6.74 \pm 0.12^{1)}$ & $6.04 \pm 0.11$ & $5.24 \pm 0.08$ & $4.61 \pm 0.06$ & $4.47 \pm 0.05$ & $4.27 \pm 0.05$ & $4.12 \pm 0.05$ \\
& & $0.1 \%$ & $6.73 \pm 0.13$ & $6.01 \pm 0.11$ & $5.22 \pm 0.06$ & $4.59 \pm 0.03$ & $4.47 \pm 0.04$ & $4.31 \pm 0.03$ & $4.09 \pm 0.03$ \\
\cline { 3 - 9 } & & $0 \%$ & $0.14 \pm 0.00$ & $0.22 \pm 0.01$ & $0.57 \pm 0.02$ & $0.85 \pm 0.03$ & $1.10 \pm 0.06$ & $1.24 \pm 0.06$ & $1.27 \pm 0.07$ \\
$\begin{array}{c}\text { Titratable acidity } \\
\text { (\%) }\end{array}$ & Safflower seed oil & $0.1 \%$ & $0.14 \pm 0.01$ & $0.22 \pm 0.01$ & $0.55 \pm 0.02$ & $0.83 \pm 0.02$ & $1.11 \pm 0.06$ & $1.25 \pm 0.06$ & $1.26 \pm 0.05$ \\
\cline { 3 - 10 } & & $0 \%$ & $5.2 \times 10^{7}$ & $8.2 \times 10^{7}$ & $4.3 \times 10^{8}$ & $1.2 \times 10^{9}$ & $3.3 \times 10^{9}$ & $6.4 \times 10^{9}$ & $6.2 \times 10^{9}$ \\
$\begin{array}{c}\text { Lactic acid bacteria } \\
(\mathrm{CFU} / \mathrm{mL})\end{array}$ & Safflower seed oil & $0.1 \%$ & $5.2 \times 10^{7}$ & $8.0 \times 10^{7}$ & $4.4 \times 10^{8}$ & $1.0 \times 10^{9}$ & $3.4 \times 10^{9}$ & $6.2 \times 10^{9}$ & $6.1 \times 10^{9}$ \\
\hline
\end{tabular}

${ }^{1)}$ Data shown are means $\pm \mathrm{SD}$ values of duplicate determinations from 3 separate experiments.

Table 4. Characteristics of fermented milk during the storage period

\begin{tabular}{|c|c|c|c|c|c|c|c|}
\hline & & & \multicolumn{5}{|c|}{ Storage period (days) } \\
\hline & & & 0 & 7 & 14 & 21 & 28 \\
\hline \multirow{2}{*}{$\mathrm{pH}$} & \multirow{2}{*}{ Safflower seed oil } & $0 \%$ & $4.61 \pm 0.05^{1)}$ & $4.40 \pm 0.04$ & $4.37 \pm 0.05$ & $4.32 \pm 0.04$ & $4.28 \pm 0.04$ \\
\hline & & $0.1 \%$ & $4.59 \pm 0.06$ & $4.42 \pm 0.05$ & $4.38 \pm 0.05$ & $4.33 \pm 0.05$ & $4.30 \pm 0.04$ \\
\hline \multirow{2}{*}{ Titratable acidity (\%) } & \multirow{2}{*}{ Safflower seed oil } & $0 \%$ & $0.85 \pm 0.02$ & $1.10 \pm 0.05$ & $1.14 \pm 0.05$ & $1.18 \pm 0.06$ & $1.20 \pm 0.06$ \\
\hline & & $0.1 \%$ & $0.83 \pm 0.03$ & $1.10 \pm 0.06$ & $1.13 \pm 0.05$ & $1.16 \pm 0.05$ & $1.17 \pm 0.06$ \\
\hline \multirow{2}{*}{$\begin{array}{l}\text { Lactic acid bacteria } \\
\text { (CFU/mL) }\end{array}$} & \multirow{2}{*}{ Safflower seed oil } & $0 \%$ & $1.2 \times 10^{9}$ & $3.1 \times 10^{9}$ & $6.5 \times 10^{9}$ & $7.2 \times 10^{9}$ & $8.6 \times 10^{9}$ \\
\hline & & $0.1 \%$ & $1.0 \times 10^{9}$ & $3.3 \times 10^{9}$ & $6.3 \times 10^{9}$ & $7.4 \times 10^{9}$ & $8.4 \times 10^{9}$ \\
\hline $\begin{array}{l}\text { CLA contents } \\
(\mathrm{mg} / 100 \mathrm{~mL})\end{array}$ & Safflower seed oil & $0.1 \%$ & $101.23 \pm 1.89$ & $102.08 \pm 1.76$ & $100.23 \pm 1.69$ & $99.40 \pm 1.53$ & $98.25 \pm 1.39$ \\
\hline
\end{tabular}

${ }^{1)}$ Data shown are means \pm SD values of duplicate determinations from 3 separate experiments. 
bacteria, and CLA content were also measured during storage for 28 days (Table 4). The $\mathrm{pH}$ level of fermented milk without added safflower seed oil decreased by $0.33 \%$ from 4.61 to 4.28 after 28 days of storage, whereas the titratable acidity increased by $0.32 \%$ from 0.85 to 1.20 . Changes in lactic acid bacteria counts were not significant. These results suggest that addition of safflower seed oil does not affect the overall quality of fermented milk. Serafeimidou et al. (39) measured the CLA content of cow fermented milk and sheep fermented milk during storage at $5^{\circ} \mathrm{C}$ for 14 days. They observed that CLA content of fermented cow milk decreased while that of fermented sheep milk increased. In our study, the contents of CLA were maintained at $0.1 \%$ of the total CLA content during the storage period ( 2 weeks).

\section{Acknowledgement}

This work was supported by a grant from the Agro-Food Frontier Cluster Project funded by the Imsil-Gun in 2015.

\section{References}

1. Koba K, Yanagita T (2014) Health benefits of conjugated linoleic acid. Obesity Res Clin Pract, 8, 525-532

2. Nagao K, Yanagita T (2005) Conjugated fatty acids in food and their health benefits. J Biosci Bioeng, 100, 152-157

3. Hur SJ, Park GB, Joo ST (2007) Biological activities of conjugated linoleic acid (CLA) and effects of CLA on animal products. Livestock Sci, 110, 221-229

4. Pariza MW, Hargraves WA (1985) A beef-derived mutagenesis modulator inhibits initiation of mouse epidermal tumors by 7,12-dimethylbenz[a]anthracene. Carcinogenesis, 6, 591-593

5. Prandini A, Sigolo S, Piva G (2011) A comparative study of fatty acid composition and CLA concentration in commercial cheeses. J Food Compos Anal, 24, 55-61

6. Nunes JC, Torres AG (2010) Fatty acid and CLA composition of Brazilian dairy products, and contribution to daily intake of CLA. J Food Compos Anal, 23, 782-789

7. Collomb M, Butikofer U, Sieber R, Jeangros B, Bosset JO (2002) Composition of fatty acids in cow's milk fat produced in the lowlands, mountains and highlands of 8. Switzerland using high-resolution gas chromatography. Int Dairy J, 12, 649-659
8. Lin H, Boylston TD, Chang MJ, Luedecke LO, Shultz TD (1995) Survey of the conjugated linoleic acid contents of dairy products. J Dairy Sci, 78, 2358-2365

9. Corino C, Magni S, Pastorelli G, Rossi R, Mourot J (2003) Effect of conjugated linoleic acid on meat quality, lipid metabolism, and sensory characteristics of dry-cured hams from heavy pigs. J Anim Sci, 81, 2219-2229

10. Kelly ML, Berry JR, Dwyer DA, Griinari JM, Chouinard PY, Van Amburgh ME, Bauman DE (1998) Dietary fatty acid sources affect conjugated linoleic acid concentrations in milk from lactating dairy cows. J Nutr, 128, 881-885

11. Song KB, Song IB, Gu HJ, Na JY, Kim SH, Yang HS, Lee SC, Huh CK, Kwon JK (2016) Anti-diabetic effect of fermented milk containing conjugated linoleic acid on type II diabetes mellitus. Korean J Food Sci Anim Resour, 36, 170-177

12. Merat S, Casanada F, Sutphin M, Palinski W, Reaven PD (1999) Western-type diets induce insulin resistance and hyperinsulinemia in LDL receptor-deficient mice but do not increase aortic atherosclerosis compared with normoinsulinemic mice in which similar plasma cholesterol levels are achieved by a fructose-rich diet. Arterioscler Thromb Vasc Biol, 19, 1223-1230

13. O'Shea M, Bassaganya-Riera J, Mohede ICM (2004) Immunomodulatory properties of conjugated linoleic acid. Am J Clin Nutr, 79, 1199-1206

14. Dilzer A, Park Y (2012) Implication of conjugated linoleic acid (CLA) in human health. Crit Rev Food Sci Nutr, 52, 488-513

15. Kim JH, Kim YJ, Park YH (2015) Conjugated linoleic acid and postmenopausal women's health. J Food Sci, 80, 1137-1143

16. Fritsche J, Rickert R, Steinhart H, Yurawecz MP, Mossoba MM, Sehat N, Roach JAG, Kramer JKG, Ku Y (1999) Conjugated linoleic acid (CLA) isomers: Formation, analysis, amounts in foods, and dietary intake. Fett-Lipid, 101, 272-276

17. Campbell W, Drake MA, Larick DK (2003) The impact of fortification with conjugated linoleic acid (CLA) on the quality of fluid milk. J Dairy Sci, 86, 43-51

18. Enser M, Scollan ND, Choi NJ, Kurt E, Hallett K, Wood JD (1999) Effect of dietary lipid on the content of conjugated linoleic acid (CLA) in beef muscle. Anim Sci, 69, 143-146

19. Du M, Ahn DU, Nam KC, Sell JL (2000) Influence of dietary conjugated linoleic acid on volatile profiles, color and lipid oxidation of irradiated raw chicken meat. Meat 
Sci, 56, 387-395

20. Bell JA, Griinari JM, Kennelly JJ (2006) Effect of safflower oil, flaxseed oil, monensin, and vitamin $\mathrm{E}$ on concentration of conjugated linoleic acid in bovine milk fat. J Dairy Sci, 89, 733-748

21. Patel KM, Morrisett JD, Sparrow JT (1979) A convenient synthesis of phosphatidylcholines: Acylation of sn-glycero3-phosphocholine with fatty acid anhydride and 4-pyrrolidinopyridine. J Lipid Res, 20, 674-677

22. Hong SI, Kim YH, Kim CT, Kim IH (2011) Enzymatic synthesis of lysophosphatidylcholine containing CLA from sn-glycero-3-phosphatidylcholine (GPC) under vacuum. Food Chem, 129, 1-6

23. Adamczak M, Bornscheuer UT, Bednarski W (2008) Properties and biotechnological methods to produce lipids containing conjugated linoleic acid. Eur J Lipid Sci Technol, 110, 491-504

24. Kishino S, Ogawa J, Yokozeki K, Shimizu S (2009) Microbial production of conjugated fatty acids. Lipid Technol, 21, 177-181

25. Andrade JC, Ascencao K, Gullon P, Henriques S, Pinto J, Rocha-Santos TA, Freitas AC, Gomes AM (2012) Production of conjugated linoleic acid by food-grade bacteria: A review. Int J Dairy Technol, 65, 467-481

26. Ledoux M, Chardigny JM, Darbois M, Soustre Y, Sebedio JL, Laloux L (2005) Fatty acid composition of French butters, with special emphasis on conjugated linoleic acid (CLA) isomers. J Food Compos Anal, 18, 409-425

27. Werner SA, Luedecke LO, Shultz TD (1992) Determination of conjugated linoleic acid content and isomer distribution in three Cheddar-type cheeses: Effects of cheese cultures, processing, and aging. J Agric Food Chem, 40, 1817-1821

28. Kim YJ, Liu RH (2002) Increase of conjugated linoleic acid content in milk by fermentation with lactic acid bacteria. J Food Sci, 67, 1731-1737

29. Roz AE, Bard JM, Huvelin JM, Nazih H (2013) The anti-proliferative and pro-apoptotic effects of the trans9, trans11 conjugated linoleic acid isomer on MCF-7 breast cancer cells are associated with LXR activation. Prostaglandins, Leukotrienes Essent Fatty Acids, 88, 265-272
30. Gorissen L, Vuyst LD, Raes K, Smet SD, Leroy F (2012) Conjugated linoleic and linolenic acid production kinetics by bifidobacteria differ among strains. Int J Food Microbiol, 155, 234-240

31. Renes E, Linares DM, Gonzale L, Fresno JM, Tornadijo ME, Stanton C (2017) Study of the conjugated linoleic acid synthesis by Lactobacillus strains and by different co-cultures designed for this ability. J Funct Foods, 35, 74-80

32. Ashraf R, Shah NP (2011) Selective and differential enumerations of Lactobacillus delbrueckii subsp. bulgaricus, Streptococcus thermophilus, Lactobacillus acidophilus, Lactobacillus casei and Bifidobacterium spp. in yoghurt A review, Int J Food Microbiol, 149, 194-208

33. Lee SG, Lee YJ, Kim MK, Han KS, Jeong SG, Oh MH, Jang AR, Kim DH, Bae IH, Ham JS (2010) A study on the yogurt manufacture suitability and antimicrobial activity of Lactobacillus plantarum LHB55 isolated from kimchi. J Anim Sci Technol, 52, 141-148

34. Trigueros L, Sendra E (2015) Fatty acid and conjugated linoleic acid (CLA) content in fermented milks as assessed by direct methylation. LWT-Food Sci Technol, 60, 315-319

35. Stanton C, Lawless F, Kjellmer G, Harringtion D, Devery R, Connolly JF, Murphy J (1997) Dietary influence on bovine milk cis-9, trans-11 conjugated linoleic acid content. J Food Sci, 62, 1083-1086

36. Kelley NS, Hubbard NE, Erickson KL (2007) Conjugated linoleic acid isomers and cancer. J Nutr, 137, 2599-2607

37. Ivan M, Mir PS, Koenig KM, Rode LM, Neill L, Entw T, Mir Z (2001) Effects of dietary sunflower seed oil on rumen protozoa population and tissue concentration of conjugated linoleic acid in sheep. Small Ruminant Res, 41, 215-227

38. So BC (2013) Evaluation of antioxidative activity and quality characteristics of yogurt containing flower oil and lactic acid bacteria isolated from korean traditional fermented food. MS Thesis, Dankook University, Korea, p 8

39. Serafeimidou A, Zlatanos S, Kritikos G, Tourianis A (2013) Change of fatty acid profile, including conjugated linoleic acid (CLA) content, during refrigerated storage of yogurt made of cow and sheep milk. J Food Comp Analy, 31, 24-30 